Dialectologia 26 (2021), 97-126.

ISSN: 2013-2247

Received 24 November 2019.

Accepted 6 August 2020.

\title{
WHY SPANISH HISTORICAL MORPHOSYNTAX (BADLY) NEEDS DIALECTOLOGY
}

\author{
Álvaro S. OCtAVIO dE TOledo y HUERTA \\ Universidad Autónoma de Madrid * \\ alvaro.octaviodetoledo@uam.es
}

\begin{abstract}
It has long been a prevalent idea in the history of Spanish that the surge of literary monuments in the $13^{\text {th }}$ led to the implantation of a solid standard superimposed on neighboring varieties as Castile expanded southwards. Recent research, however, has stressed the transfer of both Western and Eastern dialectal solutions into literary texts throughout the Middle Ages. A few key examples are offered here (mostly from the Early Modern period, whose morphosyntax has received far less attention) to show the importance of considering dialectal complexity in understanding syntactic innovation and diffusion in Spanish even far beyond the threshold of the Renaissance.
\end{abstract}

\section{Keywords}

historical dialectology, morphosyntax, Ibero-Romance varieties, Early Modern Spanish, spatial diffusion patterns

\section{DE CÓMO LA MORFOSINTAXIS HISTÓRICA DEL ESPAÑOL NECESITA DE MÁS DIALECTOLOGÍA}

\section{Resumen}

Por largo tiempo ha subsistido la idea de que la aparición de grandes monumentos literarios en el siglo XIII trajo consigo la implantación de un primer estándar castellano fuertemente consolidado que se superpuso a las variedades circunvecinas a medida que se extendía hacia el sur. En fecha más cercana, sin

\footnotetext{
* Facultad de Filosofía y Letras. C/ Francisco Tomás y Valiente, 1. E-28049 Madrid (Spain).
} 
embargo, se ha insistido en la intensa interacción del castellano con soluciones lingüísticas tanto occidentales como orientales a lo largo de toda la Edad Media e incluso más allá del umbral del Renacimiento. Se ofrecen aquí unos pocos ejemplos, principalmente bajomedievales y del español clásico y premoderno (épocas que han sido menos exploradas desde esta perspectiva) que subrayan la importancia de tener en cuenta la complejidad dialectal a la hora de entender cabalmente la innovación y difusión morfosintácticas en la historia lingüística del español.

\section{Palabras clave}

dialectología histórica, morfosintaxis, variedades iberorrománicas, español clásico, primer español moderno, patrones de difusión espacial

\section{A necessary truism}

This paper's main claim is that a careful observation of dialectal dynamics is crucial to a proper understanding of many (morpho)syntactic developments over time within a speech community where different but closely related varieties interact. From the point of view of many scholarly traditions in the historical study of individual languages, this statement might reasonably be regarded as a long-established, self-evident truth. ${ }^{1}$ Therefore, my aim here will not be to produce further evidence in support of this basic claim, but to prove that its vindication is still useful, and even necessary, to trace the history of grammatical elements and constructions in Spanish. This presupposes that little attention has been paid to the diatopic dimension in works devoted to the historical grammar of this language, at least as regards its European (or Peninsular) dialects at all but the earliest stages of their historical configuration. There are two fundamental reasons why this has indeed been the case until very recently, with some notable exceptions (particularly work by Yakov Malkiel, cf. e.g. Malkiel 1945, 1948): one is ideological, the other methodological. Each of them will be briefly expounded.

\footnotetext{
${ }^{1}$ Suffice it here to quote Antoine Meillet (1929: 77) for French and, more generally, Romance: “À I'histoire des langues romanes la foule des parlers locaux gallo-romans fournit des données auxquelles le français littéraire et le provençal littéraire ne sauraient suppléer". Of course, dialectal comparison can be hampered by lack of sufficient documentation for a given space at a given time, as seems to be the case for Old English: "The syntactic study of Old English can be reliably based only on one dialect: the West Saxon standard written language [...]. There is little scope for work on dialect syntax" (Fischer et al. 2000: 37).
} 
The historical treatment of those Western Romance varieties that have become standardized national languages (French, Italian, Portuguese, Spanish) results largely and maybe inevitably - from a reverse teleological construct: the entire diachronic development is contemplated from a present standpoint as a process leading to the emergence of the standard (for Spanish, cf. particularly Oesterreicher 2007; Arenas 2007, 2009). The geographic area (hence, the linguistic community) under scrutiny is defined by the current prevalence of that same standard, and special attention is paid to that particular variety (if any) on which the standard is more closely based. Within such a historical construct, the old 'dialect' from which modern Spanish emerged is known as Castilian. Ramón Menéndez Pidal's (1926 [1950]) foundational work on the earliest attestations of written Castilian paid due attention to diatopic variation within the Central Northern Iberian space between the $10^{\text {th }} \mathrm{c}$. and the $12^{\text {th }} \mathrm{c}$ : in his masterful depiction, Early Castilian emerges not as a unified variety, but as a complex multilectal continuum with changing and rather fuzzy borders. Unfortunately, this same outstanding scholar helped build the illusion that the surge of highly elaborate literary classics in the $13^{\text {th }} \mathrm{c}$. Kingdom of Castile (which since 1230 subsumed the former Kingdom of León to the west) led to the implantation of a solid standard language superimposed on neighboring varieties as Castile expanded (with a key moment in the conquest of Western Andalusia, ca. 1230-1250) and gained economic and political dominance over other Peninsular territories: in the form of a constantly broadening wedge, Menéndez Pidal claimed, Castilian forced its way southward and sideward, leaving behind its triumphal march nothing but faint traces of prior isoglosses (cf. principally Fernández-Ordóñez 2010). ${ }^{2}$ Thus, in this view, from the $13^{\text {th }} \mathrm{c}$. onwards Castilian is no longer a cover name for a bundle of related dialects displaying common traits along considerable differences, but the tendentiously unitary and stable, ever more widespread, highly prestigious language

\footnotetext{
${ }^{2}$ In Menéndez Pidal's (1926 [21950]: 513-514) own words: “El gran empuje que Castilla dio a la reconquista por Toledo y Andalucía y el gran desarrollo de la literatura y cultura castellanas trajeron consigo la propagación del dialecto castellano [...]: la nota diferencial castellana obra como una cuña que, clavada en el Norte, rompe la antigua unidad de ciertos caracteres comunes románicos [...], borrando los dialectos mozárabes y en gran parte también los leoneses y aragoneses, y ensanchando cada vez más su acción de norte a sur para implantar la modalidad especial lingüística nacida en el norte cántabro" [emphasis mine].
} 
of the Kingdom of Castile as manifested in its rich literature. ${ }^{3}$ As a result, internal variation within the political borders of the territory is tacitly minimized at a rather early stage of its linguistic history.

As most scholars of his time, Menéndez Pidal focused mainly on phonetic change, not changes in the grammar, to characterize linguistic evolution. Had he taken (morpho)syntactic facts more strongly into account, Castile's linguistic heterogeneity throughout the Middle Ages (and beyond) would possibly have struck him as evident. However, later interest on historical Spanish morphology and syntax has seldom helped much in producing a more nuanced diatopic picture, mainly due to changes in the methodological approach: Menéndez Pidal still saw himself as a historian trying to account for the social life of a community through their legacy of written and oral records (cf. Garatea 2005, Cano 2005); scholars working in (strict or vague) obedience to the tenets of the structuralist and formalist models that dominated syntactic research in the $20^{\text {th }}$ century, on the other hand, have aimed at reconstructing structured sets of grammatical differentiations within an internalized linguistic system, a stance not likely to focus on the social dynamics of the spread, competition or substitution of linguistic forms displayed by dialect contact. In the last four decades, the increasingly central role assumed by grammaticalization and constructionalization studies in accounting for grammatical variation and change has not necessarily favored a sociohistorical approach to dialectal data or a diatopic perspective on variation and change altogether. Focusing mainly on how changes in elements or constructions come about, these studies deal mostly with linguistic innovation, rarely having much to say about the linguistic diffusion of the forms or strings under consideration. ${ }^{4}$

\footnotetext{
${ }^{3}$ This goes along with a significant appraisal of the literary texts produced in that realm: "At the heart of Menéndez Pidal's linguistic Castilian nationalism there lay a literary nationalism" (Fernández-Ordóñez 2010: 118). As a consequence, "[d]espite not taking into account [...] any textual evidence other than the literary, Menéndez Pidal managed to establish his oversimplified view of the history of the Spanish language from the thirteenth century on. This vision has meant that subsequently only a very few scholars have made the effort to formulate a dialectal account of the history of the Spanish language" (Fernández-Ordóñez 2010: 124-125).

${ }^{4}$ As Oesterreicher (2006: 146) points out, "la pregunta por las estrategias de creación [...] debería siempre ir seguida de preguntas acerca de las vías discursivas de difusión y de adopción sucesiva de estas innovaciones por parte de los hablantes"; Sociohistorical approaches are indeed starting to make headway in historical research on Spanish and successfully combining with grammaticalisation studies (see e.g. the papers by Tuten \& Tejedo 2011 and Torres Cacoullos 2011, as well as many of the studies gathered in HernándezCampoy \& Conde-Silvestre (eds.) 2012, and references therein), although a specific dialectological
} 
Thus, the still ongoing impact of an ideology-laden account that relates Castile's increasing geopolitical dominance to the alleged linguistic uniformity of the whole territory under the influence of a prestigious literary norm as early as in the $13^{\text {th }} \mathrm{c}$. combines with a widespread disregard for social (including dialectal) variation in most current models of syntactic change to produce a largely 'de-dialectalized' view on the grammatical evolution of Castilian, hence of Spanish. Recent research, however, has stressed the ongoing transfer of both Western and Eastern dialectal solutions into literary texts produced in Castile throughout the Middle Ages (cf. Fernández-Ordóñez 2004, 2011 and references therein; Pato 2009, 2013; Rodríguez Molina 2010, 2015; Enrique-Arias 2012: 101-104; Matute 2013, 2016; Bouzouita 2016; Garachana 2016, among others). In line with these contributions, in what follows, several examples from my own research will be offered to enforce the idea that dialect contact can be and has been an important source of (morpho)syntactic innovations (loans) across varieties of Spanish. In many cases, as will be seen, chances of generalization and eventual adoption (or rebuttal, leading to isolation for both the phenomenon and the dialects that retain it) have been crucially mediated by the varieties' prestige at a given time. Furthermore, examples from all major periods of the linguistic history of Castilian / Spanish ${ }^{5}$ from the 13th c. onwards will be introduced, thus showing that the impact of dialectal dynamics on morphosyntactic innovation is not restricted to the Middle Ages, but reaches far beyond the standardization processes fostered by the political reunion of the Iberian territories under the Catholic Kings, the massive spread of printed books and the great leap forward in literary elaboration brought about by the Renaissance.

perspective on grammatical change is still wanting in most sociohistorical papers (for quite recent exceptions concerning the history of Spanish varieties, cf. also Enrique-Arias 2018, 2019, Barrio 2018, Gomila 2016, Moral 2015, Paredes 2015, Sánchez-Prieto \& Vázquez Balonga 2018 and Sánchez Prieto 2019, among others).

${ }^{5}$ Spanish is traditionally divided into four main periods: primitive or "original" $\left(9^{\text {th }}-12^{\text {th }} c\right.$. ), medieval $\left(13^{\text {th }}\right.$ $15^{\text {th }}$ c.), classical $\left(16^{\text {th }}-17^{\text {th }}\right.$ c.) and modern (from the $18^{\text {th }}$ c.) (cf. Martínez Alcalde \& Quilis [1996], Eberenz [1991, 2009]). Evidence in this paper stems mostly from data recovered from the CORDE, a large electronic corpus of written records designed for diachronic research on Spanish. As an anonymous reviewer points out, it must be noted that "the written norm does not automatically equate with the oral norm" (for our very limited chances to reconstruct orality in past stages, cf. Kabatek 2013) and, as another reviewer remarks, linguistic atlases and other dialectal materials can also be used fruitfully for diachronic purposes. The utility (and the perils) of exploiting the CORDE have been addressed elsewhere: cf. Octavio de Toledo (2016d), Rodríguez Molina \& Octavio de Toledo (2017). 


\section{Central Castilian as a linguistic island}

One strong argument against Menéndez Pidal's vision of a rampant Castilian variety capable of imposing its linguistic particularities on neighboring dialects is provided by those phenomena which, although characteristic to the central area of the $13^{\text {th }} \mathrm{c}$. realm, never managed to spread either laterally, into the western and eastern flanks of the realm, or southward, beyond the territory around Toledo (under Castilian control already by the end of the $11^{\text {th }}$ c.) and into Andalusia. Such is the case of possibly the most renowned Central Castilian syntactic innovation, namely leismo or the presence of a mass / count distinction in third person accusative clitic pronouns that opposes 10 , with continuous reference, to feminine la and masculine le (originally the dative clitic form) for discontinuous entities. Fernández-Ordóñez (2001, 2006-2007) has established the phenomenon's present-day geographical distribution (Map 1) and has convincingly advocated for historical uniformity, i.e. the correspondence of the current distribution with its maximal expansion, which it must have achieved around the $12^{\text {th }} \mathrm{c}$. and the early $13^{\text {th }} \mathrm{c}$.

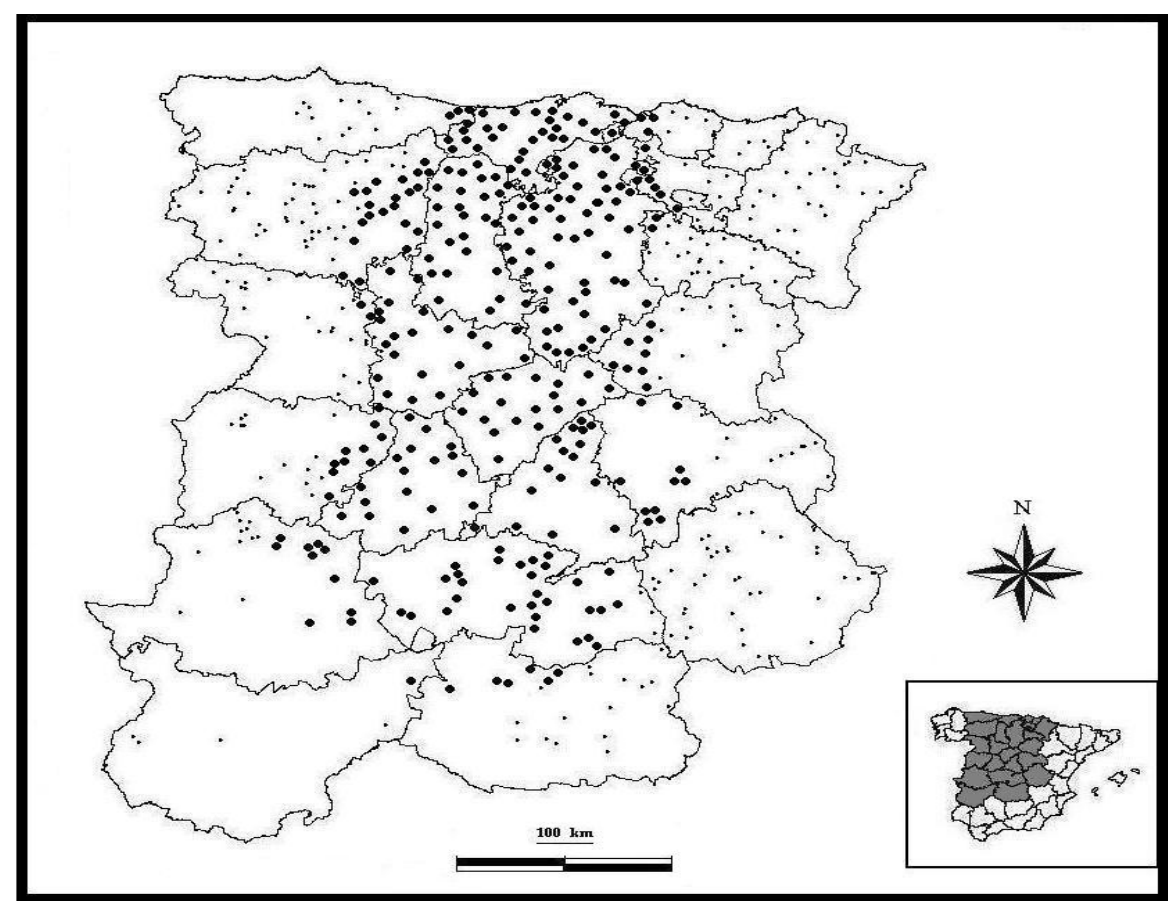

Map 1. Accusative clitics lo for mass and le for count entities (from Fernández-Ordóñez 20062007, reproduced with the author's permission). 
The failure of the leismo distinction to extend beyond these areas challenges not only the wedge-like diffusion pattern proposed by Menéndez Pidal, but also the vigor itself of the allegedly dominant (Central) Castilian variety from the $13^{\text {th }} \mathrm{c}$. onwards. After this date, this Castilian innovation appears unable to influence its eastern or western cognate varieties or insinuate itself into the emerging southern dialects. Other phenomena show a similar behavior: many Romance varieties, including contemporary Catalan, Galician and Portuguese, display a long (etymologically and phonetically regular) and a shortened form for the first person plural of the verb derived from Lat. HABĒRE (cat. havem / hem, port. havemos / hemos, gal. habemos / hemos). In these varieties, both forms have been possible in any syntactic context: as auxiliaries in Perfects, where they appear with a past participle (cf. Eng. we have written) as well as in the deontic periphrasis with the infinitive (cf. Eng. we have to write) and also as full possessive verbs (cf. Eng. we have a cottage / much hope) until HABĒRE forms were replaced in this function by the heirs of TENEERE around the $14^{\text {th }}-15^{\text {th }} \mathrm{c}$. (cf. Garachana 1997, Delport 2004, Hernández Díaz 2006, Barrio 2016). Up to the mid-15 $5^{\text {th }}$ c., however, Central Castilian only tolerated the long form habemos in all contexts but a peculiar futurate periphrasis with the infinitive and an intervening clitic (cluster), the so-called 'analytic future' escribir=(se)lo hemos ('we shall write it (to her)': cf. Castillo 2002, Company Company 2006, Girón 2007, Bouzouita 2011, Octavio de Toledo 2015a, Batllori 2016), where only short hemos was allowed: thus, unlike neighboring Aragonese, Riojan and Basque Romance (to the east) or Leonese (to the west), which from the earliest extant documents behave like Catalan or Galician-Portuguese (Map 2), Central Castilian still kept a strict syntactic divide between hemos in analytic futures and habemos everywhere else as late as 1425 , and only very scantily employed hemos in any other function until 1500. 


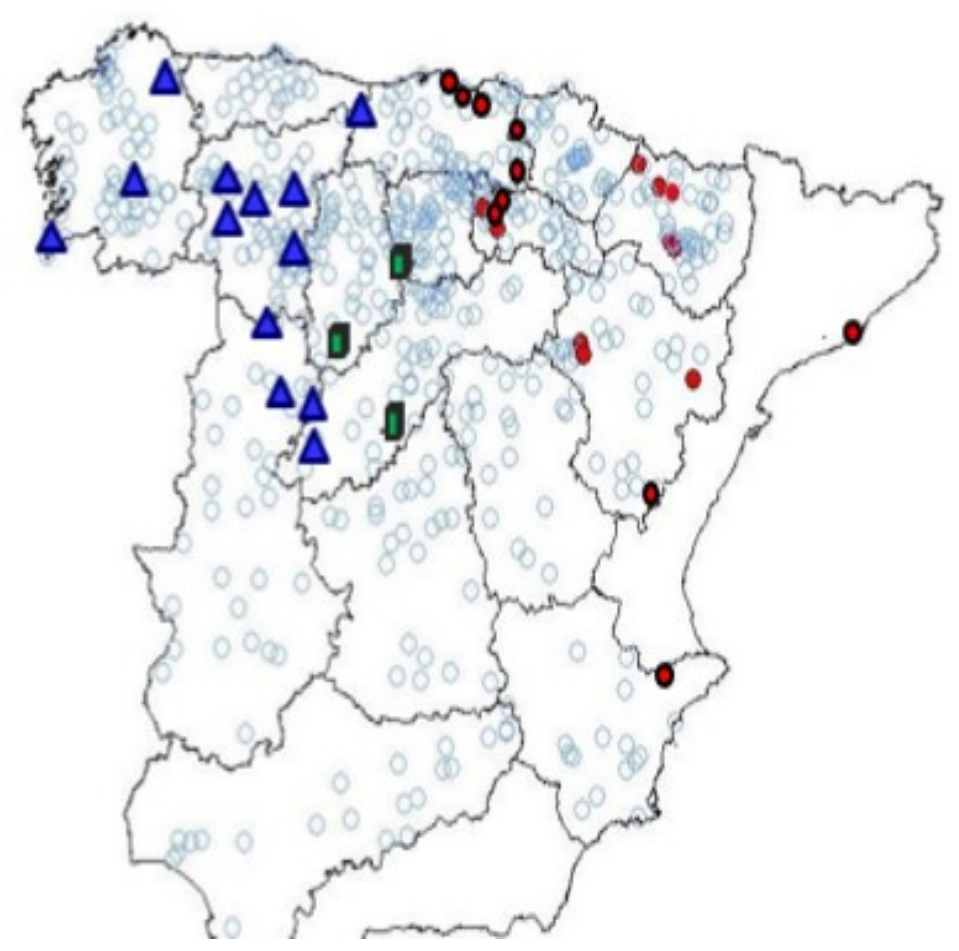

Map 2. Early (pre-15 ${ }^{\text {th }}$ c.) western (triangles) and eastern (circles) attestations of shortened hemos as a full verb or auxiliary vs. late (post 1425) similar attestations in Central Castile (rectangles). Data gathered from Rodríguez Molina (2012) and an exhaustive search of the CORDE, CODEA+, CICA and TMILG corpora.

During the first half of the $16^{\text {th }}$ c., Central Castilian swiftly adopted hemos in the remaining surroundings: ${ }^{6}$ since the habemos / hemos opposition in that variety was sensitive to syntactic context, the shortened form extended first to the deontic periphrasis with the infinitive, which was formally and semantically closer to the 'analytic futures' that had always displayed hemos. As Table 1 shows, the impact of the shortened form was much greater on this construction (70\%) than on perfects (just $41 \%$ ) during the first third of the $16^{\text {th }}$ c., whereas occurrences of the verb as a full lexical predicate strongly tended to preserve long habemos (83\%): this suggests a gradual contextual extension from the deontic to the tense-aspect auxiliary function and only then into the few remaining full verb usages.

\footnotetext{
${ }^{6}$ There could also be an additional motivation for morphological symmetry behind this extension: as second person plural habedes (< HABĒTIS) had reduced to habéis as part of a general process of /-d-/ loss in the des verbal ending during the $15^{\text {th }}$ c., the new, two-syllable habeis could have put pressure on three-syllable habemos to be similarly reduced into two-syllable hemos (cf. Bustos Gisbert \& Moreno Bernal [1992] for this line of reasoning).
} 


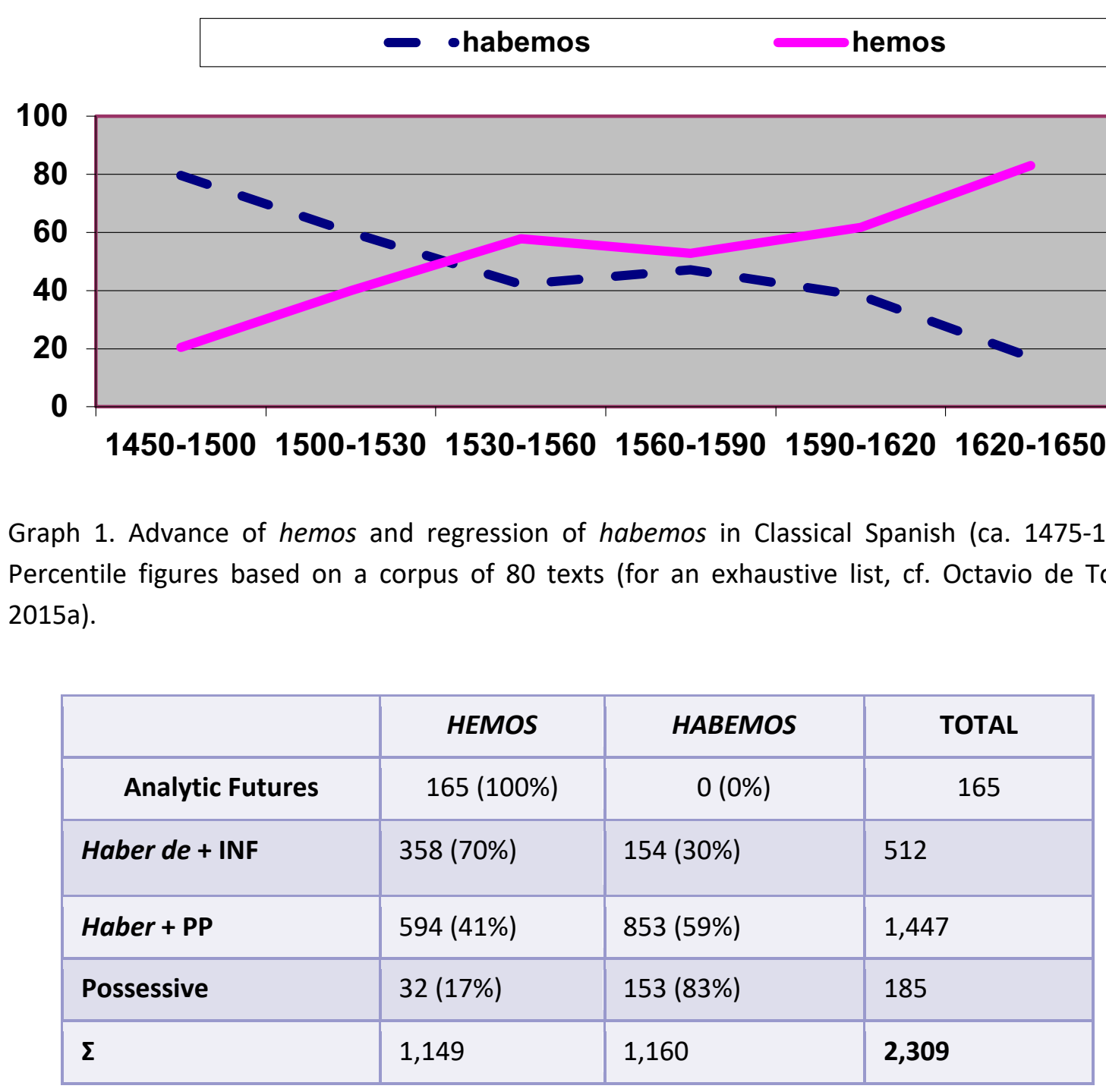

Table 1. Contextual distribution of habemos and hemos in 1501-1530 (data from the CORDE). Percentile figures refer to the proportional association of each form to each particular context.

Unlike other varieties, Central Castilian extended hemos to the exclusion of its long counterpart, a process that was completed by 1650 . Other regions, however, preserved the habemos - hemos alternation as they had been (i.e. irrespective of the syntactic context) for a very long time and even up to the present (cf. Castillo Lluch \& Octavio de Toledo 2016), although pressure from the modern standard language, based precisely on Central Castilian usage, has contributed to the marginalization of the habemos form from 
the late $17^{\text {th }}$ c. onwards. ${ }^{7}$ Andalusia and the Americas are once again among the regions that have preserved habemos more vigorously in the whole array of available constructions, ${ }^{8}$ a fact indicative of the isolation of at least some Central Castilian morphosyntactic options not only in Medieval, but also in Early Modern times.

\section{Castile and the east-west divide}

The distribution of a considerable number of lexical options in $20^{\text {th }}-21^{\text {st }} \mathrm{c}$. dialectal surveys (cf. Morala 2002, Fernández-Ordóñez 2011: 33-34) has revealed the existence of a consistent watershed that splits the territory corresponding to the old $13^{\text {th }} \mathrm{c}$. kingdom into two almost symmetrical halves roughly along a north-to-south arch running somewhat to the west of Santander, Palencia and Toledo. East of that line, the options often correspond to those of eastern Iberian regions along the middle course of the Ebro (Rioja, Navarra, Aragón), while the western half tends to conform with solutions found in (old and modern) Asturian-Leonese, Galician or Portuguese. This "crack within Castile itself" (Fernández Ordóñez 2011: 33) tells of an undeniable internal heterogeneity as well as of solidarities with neighboring areas outside the realm which contradict Menéndez

\footnotetext{
${ }^{7}$ This marginalization is related to the increasingly important role played by Madrid as an economic, political, and cultural centre from the late 16th c. onwards. Madrid is within the Central Castilian area that adopted leismo and ceased to use habemos, and its Central Castilian usage served as the base for the literary standard that dominated Classical Spanish, especially as many of the predominant authors in that period (Cervantes, Lope de Vega, Quevedo, Tirso de Molina, Calderón...) were born and raised in or around Madrid (see Bustos Gisbert \& Santiago Lacuesta [2002] for a review). The period extending from ca. 1675 to ca. 1820 marked the zenith of Madrid's linguistic prestige, when writers from every other region would seek to imitate leismo and refrain from using habemos, thus adopting Madrilean options alien to their own dialectal usage. Language policies subsequent to the independence of the American republics and the incremental influence of grammatical works by the Real Academia Española on primary education and cultivated elites led to a modulation of leísmo usage, while habemos continued to wane: in this respect, it could be noted that while leísmo openly counters an alternative present in the competence of speakers outside Central Castile (who privilege $l o$, not le, for any masculine referent in the accusative), the generalization of hemos only favors an option already present in those speakers' usage, and one that is furthermore not associated with any particular grammatical content. This could help explain why the morphosyntactic option based on Central Castilian usage has eventually come to be less successful in the case of leísmo.

${ }^{8}$ Contemporary existential (or presentative) habemos, as in habemos muchos pobres aquí ('there are many poor people here, including us') is a specialized remnant of a former full lexical construction (literally 'we have many poor people here') which can be found in informal speech in all non-central varieties of Peninsular Spanish, as well as across American Spanish varieties (cf. Octavio de Toledo y Huerta \& Castillo Lluch [2016] for relevant data and an analysis of the diachronic evolution of this construction).
} 
Pidal's picture of a unitary, strongly differentiated Castilian variety by the turn of the $13^{\text {th }}$ c. Instead, contrasts between an Eastern and a Western Castilian variety were assuredly present at that time. These contrasts were preserved throughout the Middle Ages and had an influence in the configuration of a first Spanish standard along the Early Modern period, as discussed below.

An interesting east-west dividing isogloss is found with adverbial locative sequences formed by a preposition followed by the nouns cima or somo (both originally meaning 'top' or 'summit'), of which encima 'on top, above, over' survives in the modern language as the main adverb to express superiority (whether spatial or abstract), whereas others, such as de cima 'from above, down', a cima 'up (to the top)' or por cima 'over', survived until the $15^{\text {th }} \mathrm{c}$. and even into the $16^{\text {th }} \mathrm{c}$., along with the corresponding formations with somo (en somo, de somo, a somo, por somo) (cf. Octavio de Toledo 2016a: 44-47). These sequences are described as merely competing alternatives (eventually leading to the demise of the somo series) in specialized literature devoted to spatial adverbs in Medieval Spanish (e.g. Sánchez Lancis 1990, Eberenz 2008 and Espinosa 2010), but their dialectal nature is never mentioned. However, a mere survey of reliable $12^{\text {th }}-14^{\text {th }} \mathrm{c}$. charters present in the CORDE corpus reveals the systematic western ascription of the cima sequences (current provinces of León, Zamora and Salamanca, plus southwestern Cantabria and the regions of Asturias, to the north, and Extremadura, to the south: (1a)) and the equally constant location of somo strings to the east of the abovementioned line (central and eastern Cantabria, easternmost Palencia, Álava, Burgos, Rioja, Segovia, Toledo, Guadalajara: (1b)), with both solutions coexisting in the province of Ávila, cut in two by the isogloss. ${ }^{9}$ Beyond Castile, instances with somo in the eastern territories of Navarre (2a) and (Central and Southern) Aragón (2b) are as easily found as westernmost

\footnotetext{
${ }^{9}$ In (1) and (2), years refer to the date present in the document, although some of them (particularly those prior to 1200) are not originals, but copies gathered in charter books (becerros) at individual monasteries between the late $12^{\text {th }} \mathrm{c}$. and the early $14^{\text {th }} \mathrm{c}$. The abbreviation Cat (for 'cathedral') refers to documents originating or preserved in diocesan archives. The list has been complemented with data from the Léxico hispánico primitivo (LHP) and some other occasional source. These data are always indicated with apud, and the sources recollected in the final bibliography. To my notice, there are only two counterexamples to the presented dialectal generalization: one document from Liébana [1081 apud LHP], in southwestern Cantabria, displays a sequence with somo, whereas another from Oña [1152 apud LHP], in Burgos, uses cima.
} 
(Galician or Portuguese) examples with cima (2c). Galician Medieval literature abounds with the latter $\left((3)\right.$, with examples from the $13^{\text {th }} \mathrm{c}$. Cantigas in praise of the Virgin), but it never reflects somo, whereas Eastern Castilian early literary works, like the Cid or Pedro Marín's Miracles of Saint Dominic, produced around Silos in Burgos (4), only use somo in these constructions. ${ }^{10}$ The differentiation is present even in two copies, one western and one eastern, of the same work: ms. O (western, early $14^{\text {th }} \mathrm{c}$.) of the Libro de Alexandre shows cima in the same strings where ms. P (eastern, 15th c.) systematically employs somo (5).

(1a) Oviedo (Asturias) [Cat: 1114, 1145 apud LHP], Avilés (Asturias) [1155], Salamanca [Cat: 1223, 1281, 1294], Eslonza (León) [1245 apud Staaf 1907: 130], Carrizo (León) [1247], León [Cat: 1255, 1257], Carrizo (León) [1273], Terradillos (Salamanca) [1282], Ávila [1294], Valdecorneja (Ávila) [1295, 1296].

Ávila [Cat, Becerro de visitaciones, ca. 1303-1310: numerous examples], León [Cat: 1307, 1308, 1310, 1324, 1329, 1334, 1347, 1398], Béjar (Salamanca) [1325], Zapardiel (Ávila) [1326], Bonilla de la Sierra (Ávila) [1335], Santo Toribio de Liébana (southwestern Cantabria) [1337, 1371,1377, 1380, 1386, 1388, 1390, 1398], Guadalupe (Cáceres) [1344, 1347], Areces (Asturias) [1345], Magazuela, Cáceres [1350], Villanueva del Campillo, Ávila [1361], Cornellana (Asturias) [1364, 1382], Potes (southwestern Cantabria) [1363], Ávila [1368], Orellana (Cáceres) [1385].

(1b) Valpuesta (Burgos) [804], Santoña (eastern Cantabria) [927, 1047, 1086], Belbimbre (Burgos) [929], Arlanza (Burgos) [929 apud LHP, 1210], Cardeña (Burgos) [972, 994], Santillana (central Cantabria) [1001 apud LHP, 1084 apud LHP], Oña (Burgos) [1014 apud LHP, 1063, 1084 apud LHP, 1085 apud LHP, 1129 apud LHP, 1219, 1237, 1256, 1276, 1279 (x4), 1281, 1282 (x2), 1283], Valvanera (Rioja) [1047 apud LHP], Silos (Burgos) [1085, 1098, 1253], El Moral (Burgos) [1124], Lerma (Burgos) [1148], Aguilar (northeastern Palencia)

\footnotetext{
${ }^{10}$ Corominas \& Pascual (1980, s.v. cima) already noted that cima "is never applied to actual mountains in the Cantigas, although the term is extremely frequent in the text in all grammaticalized contexts" [my translation, ÁOdT]. As for the exclusive use of somo in the Poema de mio Cid, cf. Coello Mesa (2004). In literary texts, combinations with cima progressed from 15 occurrences in the $13^{\text {th }} \mathrm{c}$. to 80 in the $14^{\text {th }} \mathrm{C}$., while somo decreased from 103 cases in the $13^{\text {th }} \mathrm{c}$. to just 63 in the $14^{\text {th }} \mathrm{c}$. (data from the CORDE corpus). Thus, sequences with cima represented only $13 \%$ with respect to the total amount of cima / somo sequences in the $13^{\text {th }} \mathrm{c}$., but reached $56 \%$ of that sum throughout the $14^{\text {th }} \mathrm{c}$. to become the dominant form. For further quantitative detail, cf. Octavio de Toledo (2018a).
} 
[1186], Busto de Bureba (Burgos) [ca. 1200], Cascajares de Bureba (Burgos) [1202], Ribiella de Mio Cid (Burgos) [1212], Toledo [1215], San Millán de la Cogolla (Rioja) [1241, 1242], Palencia (southeastern Palencia) [1242], Villanueva del Río (northeastern Palencia) [1259], Frías (Burgos) [1267], Ávila [Cat, 1270], Ávila [1273, 1283], Santa María de Mave (northeastern Palencia) [1278], Serranos de Avianos (Ávila) [1284], Frías (Burgos) [1290], Valdecorneja (western Ávila) [1295], El Espinar (Segovia) [1297].

Tía Amuña (Ávila) [1301], Ávila [Cat, Becerro de visitaciones, ca. 1303-1310: numerous examples], Ávila [1304, 1361], Mironcillo (Ávila) [1304], Guadalajara [1305], Campezo (Álava) [1313, 1332], San Miguel de Serrezuela (Ávila) [1315], El Espinar (Segovia) [1368], Guadalajara [1399].

(2a) Est ipsa pieza en somo de la fesa de santo petro (Fitero, 1202)

is that lot on top of the grassland of Saint Peter

'That lot is above Saint P.'s property'

nuestros casales que auemos en Orgurrun en somo de la uilla (Irache, 1254)

our houses that have.1PL in Orgurrun on top of the town

(2b) et vadit via ad somo de illa serra (Morella, 1233)

and go.3SG way to top of the ridge 'and the path ascends up the ridge' per somo de illa serra (Sástago, 1242, apud Frago 1982: 58)

across top of the ridge 'over the ridge'

(2c) et inde per cima de pincales veteros (Tuy (Pontevedra), 1138, apud Flórez 1767: 261) and hence across top of pinewoods old 'and then over the old pinewoods' pague [...] dez mijl liuras [...] e emçima a maldiçõ de Deus (São Vicente de Fora (Lissabon), 1251, apud Bello 2001: 57-58)

pay.SBJV.3SG ten thousand pounds and on.top the curse of God 'He is to pay 10,000 pounds and receive God's curse on top of that'

(3) a fonte / saborosa [...], que naç' encima $d=u n$ monte (Alfonso X, Cantigas, 48) the source savory that is.born on.top of a mountain 'The refreshing source that springs from atop the mountain' 
per cima $d=u n$ recoste (ibid.., 182)

across top of a slope 'Over a hill's slope'

os fezeron en caer [...] / mortos de cima $d=0$ muro (ibid..., 185)

them.ACC make.PFV.3PL hence fall.INF dead from top of the wall

'They let them fall dead from over the wall'

(4) poso=sse el moro en somo de=la penna (Marín, Miraglos, 55r)

rest.PFV.3SG=REFL the moor on top of the rock

subio en somo $d=e l$ altar de santo domingo \& tomo la cruz (ibid..., 87v)

climb.PFV.3SG on top of the altar of Saint Dominic and take PFV.3SG the cross

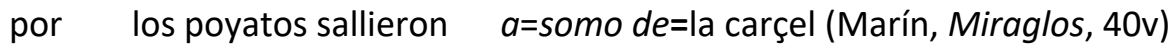

through the grips go.out.PFV.3PL to top of the prison

'They climbed up their cell by holding on to the grips (on the wall)'

(5) El Rey fincó sennero en çima d=el castiello (AlexO, 2060a) [AlexP: en somo] the king remained.PFV.3SG alone on top of.the castle salian los sudores por çima de los çerros (AlexO, 824cd) [AlexP: por somo] go.out.IMPV.3PL the sweat.PL through top of the loins

'Sweat sprouted all over their backs'

Clearly, the preference for somo or cima inside adverbial locative sequences was regulated by the dialectal origin of writers and copyists. In spite of this, cima became more broadly used in literary sources during the $14^{\text {th }} \mathrm{c}$. and ousted somo along the $15^{\text {th }} \mathrm{c}$., perhaps because of the cultural prestige of north-western literature in the vernacular during the first half of the $14^{\text {th }} \mathrm{c}$. or the apparent orientation towards Portugal in the policies of Kings Fernando IV and Alfonso XI in that same period. Thus, the western solution eventually came to be adopted by the Early Modern standard. But eastern somo, although finally isolated, experienced its own diatopic diffusion during the $13^{\text {th }} \mathrm{c}$., as it was brought by settlers from the Ebro territories into Central and Lower Aragón and even further into the interior of Valencia (cf. the arrow on Map 3) along a path described by Catalán (1972) for some lexical elements and Heap \& Pato (2012) for the activation of number agreement on the infinitive in contemporary oral varieties. Using this path, we may now add an old grammatical phenomenon that confirms the century-long 
productivity of a geolectal itinerary crossing and binding together bordering areas of four Medieval kingdoms (Castile, Navarre, Aragón and Valencia).

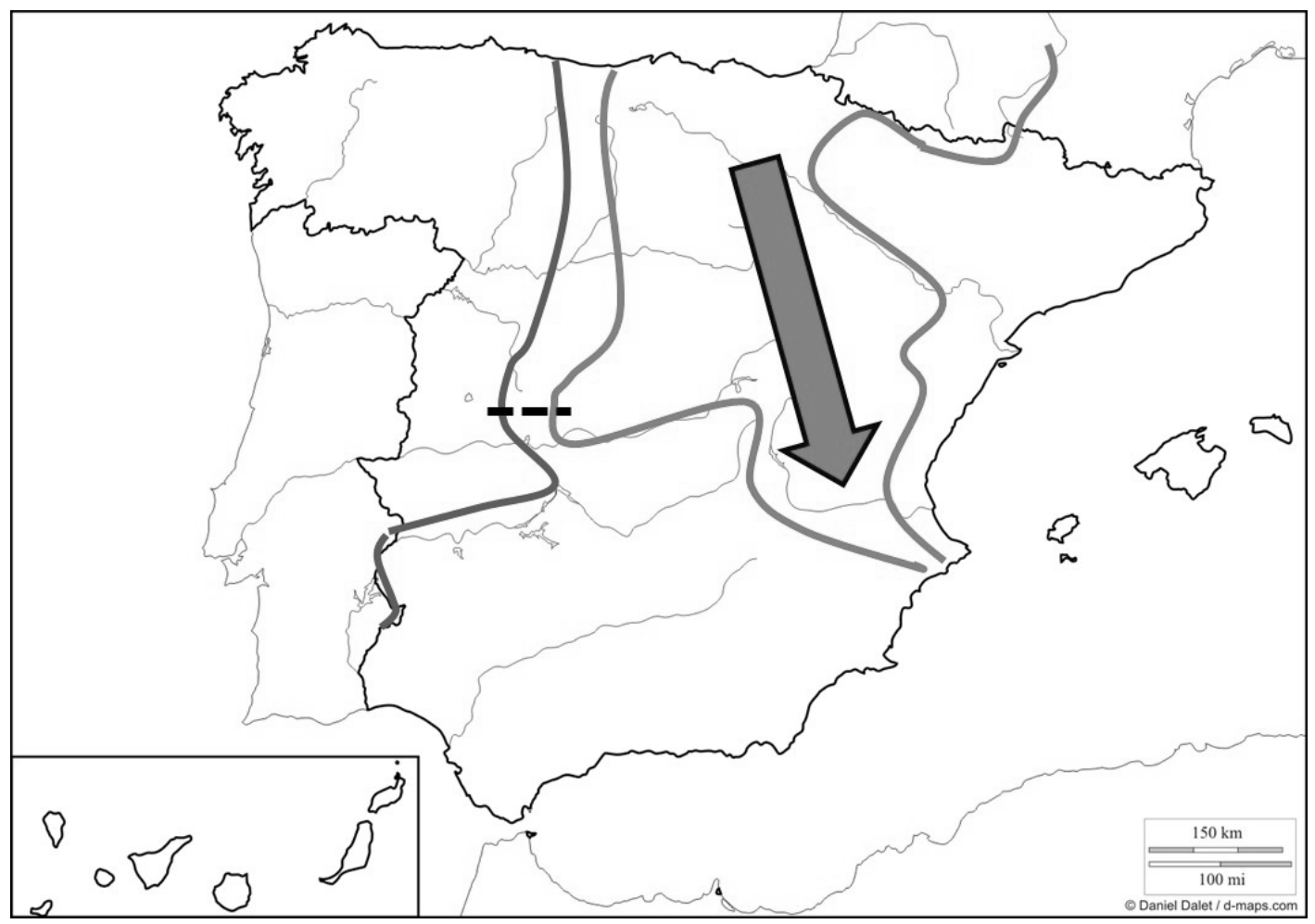

Map 3. Territories where adverbial sequences with cima (western isogloss) and somo (area delimited by the eastern isoglosses) were used to the exclusion of each other in the $13^{\text {th }}-14^{\text {th }} \mathrm{c}$. The location of the province of Ávila, where both elements coexisted, is signaled by the short horizontal dotted line. The arrow indicates the diffusion path of somo.

Political borders across kingdoms were, thus, linguistically porous, and Castile, being a central territory, was subject to the penetration (and even the coexistence) of both eastern and western grammatical elements. Apparently, the geographical direction from which significant influences arrived tended to vary over time: from the $13^{\text {th }} \mathrm{c}$. to the late $14^{\text {th }}$ c., as we have seen, western solutions could spread, gain social prestige and eventually become prevalent in the cultivated written standard, as was the case with cima-based adverbials or with the relative pronoun quien 'who' (cf. Fernández Ordóñez 2011: 83-84), whose adoption probably paved the way for the later success of the equally western indefinite alguien 'someone', present in Ávila or Madrid from the mid-15 ${ }^{\text {th }} \mathrm{c}$. onwards (cf. Malkiel 1948, Pato 2009). Eastern syntactic influence, on the other hand, 
became pervasive from the early $15^{\text {th }} \mathrm{c}$. onwards: after 1412, Aragón came under the rule of a cadet branch of the Castilian dynasty, a political turning point which tightened the bonds between the two kingdoms and created common interests and (partly) convergent policies. Castilian noblemen and clerics with intellectual ambitions often travelled to the east to become familiar with the new ways of Humanism brought into the Iberian Peninsula via the Aragonese presence in southern Italy. They came back home writing in a prose (and verse) interspersed with syntactic calques from Aragonese or Catalan (cf. e.g. Ridruejo 1984), and adopted the syntactic mechanisms with which eastern Iberian authors had translated the Italian versions of the Latin classics and also the Italian classics (principally Dante and Boccaccio) themselves (cf. Pons 2015, Octavio de Toledo 2017a). Along constructions and grammatical(ized) elements characteristic of highly elaborate written language (e.g. discourse markers: cf. Garachana 2014; Octavio de Toledo 2018b), other, more general linguistic devices were adopted or favored under this wave of eastern influence. For example, compound verbal forms with the auxiliary haber 'to have' and a participle, which were (and still largely are) entirely alien to western varieties and only weekly represented in Castile until the late $14^{\text {th }} \mathrm{c}$., became much more abundant and varied in all sorts of Castilian written sources (cf. Rodríguez Molina 2010, Bartol 2012, Octavio de Toledo 2017b), and first and second person plural personal pronouns nós / vós 'we / you.PL' were replaced by the eastern reinforced forms nosotros / vosotros (Fernández-Ordóñez 2011: 76-78). Additionally, the locative adverbs detrás 'behind' and debaxo 'below' were adopted from eastern varieties as a means of introducing locative adjuncts (behind the door, below the table: cf. Octavio de Toledo 2016a: 94-100, Rodríguez Molina \& Octavio de Toledo 2017: 19-22), thus completing a Castilian locative subsystem where another adverb prefixed with de-, delante 'in front of' had been present since the earliest documents. ${ }^{11}$

The aforementioned eastern phenomena were integrated into $15^{\text {th }} \mathrm{c}$. Castilian and rapidly entered the $16^{\text {th }} \mathrm{c}$. Spanish standard, but some syntactic behaviors were not easy

\footnotetext{
${ }^{11}$ Because western encima was already established as the locative adverb for superiority, the $15^{\text {th }} \mathrm{c}$. Castilian system (hence also $16^{\text {th }} \mathrm{c}$. Spanish) became, in terms of the dialectal origin of its members, a 'compromise' or mixed paradigm: old Castilian delante, western encima and eastern debajo and detrás grouped to form a prefixed adverbial series parallel to the non-prefixed prepositional paradigm formed by ante 'in front of , sobre 'over, on', tras 'behind' and so 'under', of which the latter would disappear around the $15^{\text {th }}$ c. (cf. Octavio de Toledo [2016a] for more details).
} 
to integrate into Castilian grammar and remained exclusively eastern during the whole Classical period $\left(16^{\text {th }}-17^{\text {th }}\right.$ c.). Castilian, for instance, never allowed a non-prefixed spatial adverb to introduce an adjunct directly (i.e. without the intervention of the auxiliary preposition de): ${ }^{12}$ thus, debaxo de la mesa and even debaxo la mesa ('under the table') became common throughout the $15^{\text {th }}$ c., and baxo de la mesa, with the non-prefixed adverbial baxo, was also adopted toward the end of that century, but baxo la mesa was not possible beyond the easternmost Castilian provinces (with a weaker irradiation into Toledo and Madrid). It was, however, quite frequent not only in manuscripts, but even in printed sources produced all throughout the eastern territories, from Pamplona in the north through Saragossa or Valencia to the border region of Murcia in the south (6a). In fact, Murcia is an area in which baxo can still be used today as a locative adverb, as shown in (6b), contrary to the standard (cf. Octavio de Toledo [2015b] for more detail). The assumption that the overarching Castilian-based Spanish literary standard was broadly accepted in all territories of the reunited kingdoms from around 1500 onwards has thus obscured the fact that even the rather standardized printed sources may bear features of dialectal syntax in the $16^{\text {th }}-17^{\text {th }}$ c. (and even later).

(6a) Mi marido está baxo la cama (Exemplario contra los engaños y peligros del mundo) My husband is under the bed [Saragossa, 1493] Estavan baxo el árbol confundidos hombres y brutos (Baltasar Gracián, Criticón, II) Were under the tree mixed men and animals [Saragossa, 1653] la prosa tiene también [...] armonia: pero [...] no la tiene baxo el rigor de lei the prose has also harmony but NEG CL.ACC has under the rigor of law 'Prose is also harmonious, though not under strict rules' (Cascales, Tablas poéticas) [Murcia, 1617]

(6b) sacaras las fezes que estan baxo (Tratado de conservar el vino, 1385-1407) withdraw.FUT.2SG the lees that are below Los policías están ahí bajo (present-day Alicante, apud Blas Arroyo 2004: 1072) The policemen are there below 'The police is down there.

\footnotetext{
${ }^{12}$ For this structural restriction in Castilian, which did not affect Eastern Iberian dialects, see Octavio de Toledo (2016a).
} 


\section{Across the ocean: eastern and western grammatical forms in the Americas}

The long-standing assumption that American Spanish varieties originated from a situation of dialect levelling heavily influenced by speakers from Western Andalusia benefiting from the prestige attached during the $16^{\text {th }} \mathrm{c}$. to Sevillian speech patterns is still widespread today (see Menéndez Pidal 1962 and Penny 2004: 139-145 for a review). It has been, however, scarcely mentioned that Eastern and Central Western syntactic phenomena also reached the Americas, whether with a broader or more constrained distribution, as did lexical elements of the same origins (see e.g. Frago 1999). Let us look at two brief examples, one for each area.

Around the end of the $16^{\text {th }}$ c. and the early $17^{\text {th }}$ c., a western morphosyntactic innovation such as the indefinite quantifier algotro 'some other (person or object)' had little opportunity to enter the already fairly consolidated, Madrid-centered standard. It did, though, manage to spread locally from its cradle in north-western Extremadura to the east of the region and into southwestern Ávila and western Toledo, possibly along the important routes that connect sheepherding regions around Talavera to Badajoz and along the quicksilver route that links southwestern La Mancha to northernmost Andalusia over Almadén and Llerena, a thriving commercial course in the $17^{\text {th }} \mathrm{c}$. and early $18^{\text {th }} \mathrm{c}$. Algotro is currently considered a nonstandard but frequently employed localism in those Spanish regions and also in many American varieties, reaching important frequencies of use in Central America (particularly El Salvador, where it can be said to be generalized and even used in formal speech), Northern Mexico, Colombia, or Chile (cf. Octavio de Toledo 2016b). Having reached the other side of the Atlantic probably along the second half of the $17^{\text {th }} \mathrm{c}$. or the early $18^{\text {th }} \mathrm{c}$., this quantifier was likely not introduced by Andalusian speakers, since migration from that region to the Americas decreased around $50 \%$ in the $17^{\text {th }} \mathrm{c}$. when compared to the $16^{\text {th }} \mathrm{c}$., and it was most heavily concentrated in the first three decades, with only around $27 \%$ of registered $17^{\text {th }} \mathrm{c}$. Andalusian migrants moving overseas after 1630 (Díaz-Trechuelo 1989). ${ }^{13}$ Rather, population data for the archbishopric of Toledo (Graph 2) showing a stark decrease during the entire $17^{\text {th }} \mathrm{c}$.

\footnotetext{
${ }^{13}$ Data from the $18^{\text {th }} \mathrm{c}$. are not significantly more favorable to Andalusian presence in the Americas: cf. Martínez? Shaw (2004).
} 
suggest a strong migratory current from that region (to Madrid, but also overseas) during this period (Ojeda 2004), which, alongside the constant presence of migrants from Extremadura, can account for the diffusion of algotro in America.

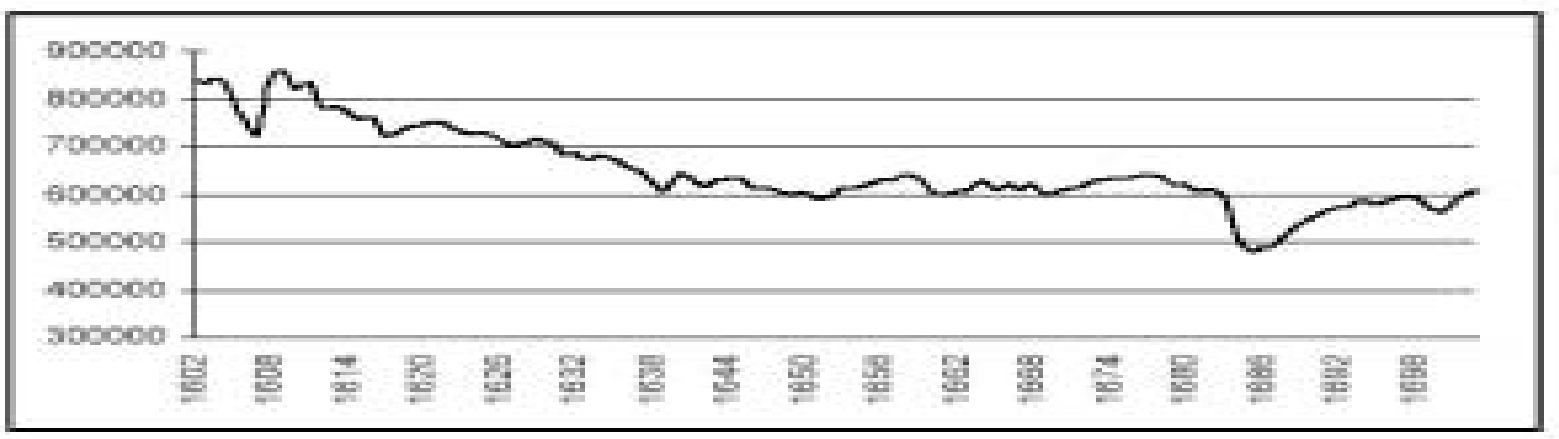

Graph 2. Population curve for the archbishopric of Toledo during the $17^{\text {th }}$ c., apud Ojeda (2004: 106).

The spatial adverbial expression en igual de 'level with, at the same height' further grammaticalized around the late $14^{\text {th }} \mathrm{c}$. and $15^{\text {th }} \mathrm{c}$. in eastern Iberian varieties (including Valencian Catalan) to develop the abstract comparative meaning 'as good as, equal to', as shown in (7a). Then, around the late $16^{\text {th }}$ c., the substitutional reading 'instead of' developed, which could head a whole sentence, as in (7b). Having reached Madrid around the late $17^{\text {th }}$ c., this latter construction was tolerated in the standard until the first decades of the $19^{\text {th }}$ c., and it appears in the first dictionary of the Real Academia, the famous Diccionario de Autoridades (cf. Octavio de Toledo 2016c). At some point in the $18^{\text {th }} \mathrm{C}$, it also travelled west over the ocean but became only weakly entrenched there: to my knowledge, en igual de 'instead of' has been retained only in Northwest Mexico (particularly in the state of Sinaloa), an area populated largely between 1650 and 1800 as a consequence of a mining boom that became rapidly marginalized soon thereafter.

(7a) Josue era quasy en egual de Moysen en razon d=el su regimiento Joshua was almost at height of Moshe in reason of.the his rule 'Joshua was almost equal to Moshe as far as his authority is concerned' (Arragel Bible [produced in Guadalajara, to the east of Madrid], gloss 2 to Jos 1:1) 
(7b) en ygual de curar la vlcera, la haze mayor in equality of healing the ulcer ACC.3SG makes bigger 'instead of healing the ulcer, it makes it grow' (Juan Calvo, Segunda parte de la medicina y cirurgia, [Valencia, 1599], II, 240)

From a broader perspective, the history of these rather minor constructions may have greater symptomatic value than it might at first sight appear. Although much research still remains to be done in this field, there are, to date, practically no signs of syntactic divergence between European and American Spanish (written) usage before the late $17^{\text {th }}$ c. (cf. Sánchez Méndez 2015). The formation of local American varieties with strong preferences for morphosyntactic options that developed different or at a different pace in the European standard commences during the $18^{\text {th }} \mathrm{c}$. (cf. Company Company 2007 for Mexico) and becomes much more active in the initial decades of the $19^{\text {th }} \mathrm{c}$. (cf. also Melis, Flores \& Bogard 2003 and Flores \& Melis 2015). Thus, morphosyntactic innovations brought from the metropolis over the second half of the $17^{\text {th }} \mathrm{c}$. still had a strong impact on American varieties (cf. e.g. Lipski 2014). This was the case of the generalization of ustedes ' $y o u$ ', a late $17^{\text {th }} \mathrm{c}$. Peninsular innovation adopted as the only second person plural pronoun for both formal and informal address during the $18^{\text {th }} \mathrm{c}$. throughout the colonies. At that point in time, even nonstandard, dialectal algotro might have had a good chance of being widely diffused in the New World. However, metropolitan innovations that reached America during the $18^{\text {th }} \mathrm{c}$. and were not clearly supported by the literary standard could already face significant local opposition from linguistically self-conscious middle or higher social strata speakers that felt increasingly detached from Spain and newly arrived Peninsular speakers, particularly in large cities that had become major political and cultural centers, such as Mexico City or Lima. Incoming constructions could become entrenched in recently populated frontiers like the Mexican Northwest (en igual de), where they have been preserved due to the ensuing isolation of the territory (see Trudgill [2011] for a discussion of the effect of dialectal isolation on the preservation of linguistic forms). In Colombia, for instance, en igual de is documented in Bogotan cultivated writers such as Caro or Cuervo up to the early 20C, but 
it was subsequently eliminated from the local standard. Such innovations could be refused in the major urban centers but accepted in more peripheral territories. This seems to have been the case with the exclamative and interrogative quantifier sequence cómo de (iCómo de grande es su fortuna! 'How big his fortune is!', ¿Cómo de lejos está tu casa? 'How far (away) is your home?'), which replaced qué tan (8a) in European Spanish along the $18^{\text {th }} \mathrm{c}$. but failed to do so in Mexico. In areas that were more closely linked to the metropolis during the early colonial era $\left(16^{\text {th }}-17^{\text {th }}\right.$ c.), such as the Peruvian area around Lima or the Colombian highlands, qué tan had also become entrenched, and cómo de was only admitted as an exclamative, not an interrogative device. However, territories that were only significantly connected to metropolitan influence during the $18^{\text {th }} \mathrm{c}$., such as Argentina or Paraguay, embraced the Peninsular innovation (8b), as did Cuba (in this latter case, probably due to more prolonged contact with Spain). Map 4 (cf. Octavio de Toledo \& Sánchez López 2007, 2009) visualizes this distribution.

(8a) ¿Qué tan grande [...] debía de ser el gigante Morgante? (Cervantes, Quijote, II, 1, 636) What so big must.IMPFV.3SG P be.INF the giant Morgante 'How big ... must have been Morgante the giant?'

(8b) [Yarini] Di=me cómo de fuerte es tu amor. [Bebo] iAy! El mío es débil [Y.] Tell.IMP=ACC.1SG how of strong is your love [B.] Oh the mine is weak [Yarini] 'Tell me how strong is your love'. [Bebo] 'Oh, mine is weak!' (Carlos Felipe [= Carlos Fernández Santana], Réquiem por Yarini, Cuba, 1960) 


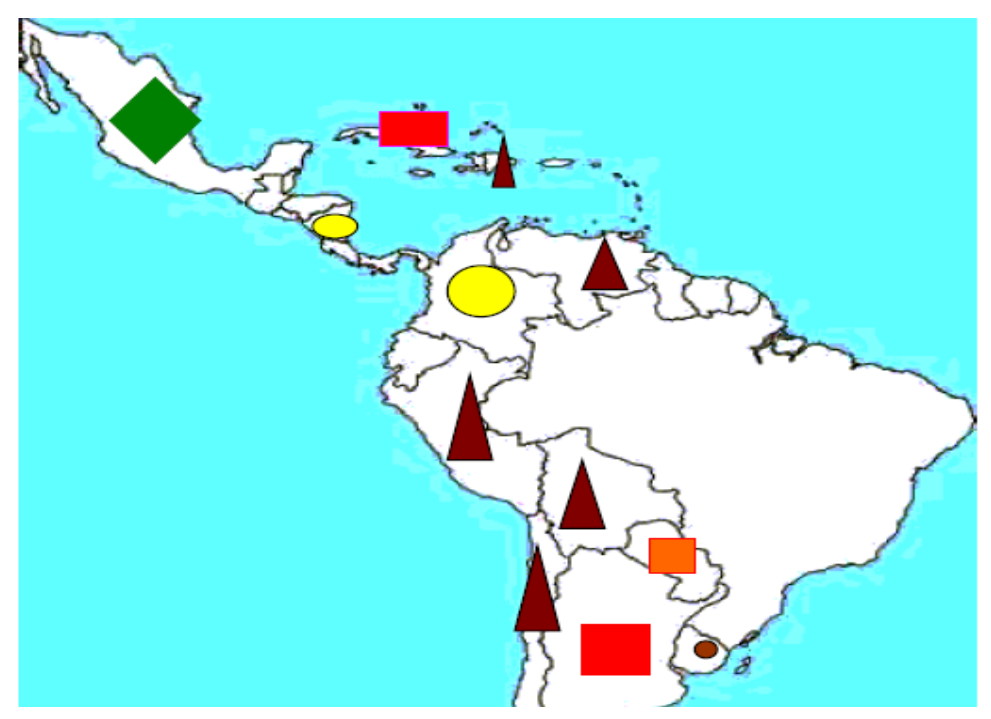

Map 4. Preference for the exclamative / interrogative quantifier qué tan (romboid) vs. preference for cómo de (squares) as recovered from searches in the CREA corpus. Circles signal a split between interrogatives (qué tan) and exclamatives (cómo de), whereas triangles indicate a scarce presence of qué tan in both contexts with cómo de dominant in exclamatives. (The size of the forms is irrelevant and serves only as a visual device for easier perception.)

\section{Concluding remarks}

To sum up, the more salient conclusions will be briefly synthesized that emerge from the various situations of dialectal isolation and contact presented throughout this study.

a) Castile was not dialectally homogeneous in the $13^{\text {th }} \mathrm{c}$. Some phenomena clearly divided the territory into two blocks, one Eastern and one Western, and these blocks shared their variants with varieties more to the east or west, respectively, with which they obviously were in close linguistic contact.

b) Central Castilian had isolating dialectal particularities which failed to spread beyond rather narrow borders through the Middle Ages and whose impact only becomes visible during the zenith of the Classical Period (ca. 1560-1650) as the Madrid-centered standard developed.

c) Castilian syntax was subject to notable influences from eastern varieties in the $15^{\text {th }} \mathrm{c}$. that were then incorporated into the $16^{\text {th }} \mathrm{c}$. Spanish literary standard.

d) Eastern varieties were able to preserve autochthonous dialectal constructions even in printed, learned sources up to the $18^{\text {th }} \mathrm{c}$. 
f) Despite the general validity of the andalucismo hypothesis, some grammatical elements and constructions which clearly originated in western and even eastern varieties reached the Americas.

g) Significant morphosyntactic divergence among American and European Spanish appears to be lacking before the $18^{\text {th }} \mathrm{c}$. Peninsular innovations prior to that date possibly had a better chance to grow roots in American soil than those diffused during the last century of the colony, which could be tolerated only in the more peripheral territories.

As has been shown here, all these matters have received attention only very recently (points 1, 2 and 6) or have been dealt with superficially, at best (points 3-5). Hopefully, the reader will deem the title of this contribution sufficiently justified and feel the urge to join Fernández-Ordóñez (2011: 70) in her demand for a new "hermeneutic model" in Spanish historical morphosyntax that may help overcome the ideological biases inherited since Menéndez Pidal's seminal work: one that pays due heed to the implications of the multilectal nature that characterizes the Ibero-Romance continuum during the Middle Ages and into the (Early) Modern period and attempts to account for the ways in which those different but related varieties interacted, sharing or preserving their grammatical properties, elements and constructions, converging and diverging via contact, expanding or recoiling, contributing their particularities to emergent standards or falling back into isolation and locality. The task is certainly vast and complex, but the results are likely to help us move beyond the mistakes of older perspectives and address promising research questions and directions in the future.

\section{References}

ARenas OlletA, Julio (2007) "Pidal y Lapesa: dos historias de la lengua", in Jochen Hafner \& Wulf Oesterreicher, (eds.), Mit Clio im Gespräch: Romanische Sprachgeschichten und Sprachgeschichtsschreibung, Tübingen: Narr, 233-254.

AREnAs Olleta, Julio (2009) "El nombre de la lengua. Lingüística y sociedad a comienzos del siglo XX en España", Boletín de la Real Academia Española, 89, 5-40. 
BARRIO DE LA ROSA, Florencio del (2016) “De tener a tener. La difusión de tener como verbo de posesión en la historia del español: Contextos y focos", in Carlota de Benito Moreno and Álvaro Octavio de Toledo (eds.), En torno a haber: construcciones, usos y variación desde el latín hasta la actualidad, Frankfurt [etc.], Peter Lang, 239-279.

BARRIO DE LA ROSA, Florencio del (2018) Espacio variacional y cambio lingüístico en español, Madrid, Visor.

Bartol Hernández, José Antonio (2012) “Habría dado con el valor dedissem”, in Emilio Montero Cartelle (ed.), Actas del VIII Congreso Internacional de Historia de la Lengua Española, vol. I, Santiago de Compostela: Meubook, 643-657.

BATLLORI, Montserrat (2016) "El valor modal de haber en los futuros y condicionales analíticos", in Carlota de Benito Moreno \& Álvaro Octavio de Toledo (eds.), En torno a haber: construcciones, usos y variación desde el latín hasta la actualidad, Frankfurt [etc.]: Peter Lang, 33-78.

Bello Rivas, María Xesús (2001) "São Vicente de Fora (Lisboa) / Montederramo (Ourense): en torno a la tradicón notarial gallego-portuguesa", in Daniel Jacob \& Johannes Kabatek (eds.), Lengua medieval y tradiciones discursivas en la Península Ibérica, Frankfurt / Madrid: Vervuert / Iberoamericana, 45-62.

BlAs ArRoyo, José Luis (2004) “El español actual en las comunidades del ámbito lingüístico catalán”, in Rafael Cano (ed.), Historia de la lengua española, Barcelona: Ariel, 1065-1086.

BouzouITA, Miriam (2011) "Future Constructions in Medieval Spanish: Mesoclisis Uncovered", in Ruth Kempson, Eleni Gregoromichelaki \& Christine Howes (eds.), The dynamics of lexical interfaces, Stanford: CSLI Publications, 91-132.

BouzouITA, Miriam (2016) "La posposición pronominal con futuros y condicionales en el códice escurialense I.i.6: un examen de varias hipótesis morfosintácticas", in Johannes Kabatek (ed.), Lingüística de corpus y lingüística histórica iberorrománica, Boston / Berlin: De Gruyter, 270-298.

Bustos Gisbert, Eugenio de \& Jesús Moreno Bernal (1992) “La asimetría hemos / habéis", in Manuel Ariza et al. (eds.), Actas del II Congreso Internacional de Historia de la Lengua Española, vol. I, Madrid: Pabellón de España, 307-321.

Bustos Gisbert, Eugenio de \& Ramón SAntiago LACUesta (2002) “Para un nuevo planteamiento de la norma madrileña (siglos XVI y XVII)”, in María Teresa Echenique \& Juan Sánchez Méndez (eds.), V Congreso Internacional de Historia de la Lengua Española, vol. II, Madrid: Gredos, pags. 1125-1136.

CANO, Rafael (2005) “¿Lengua o lengua literaria?: reflexiones en torno a los estudios lingüísticos sobre el español de los Siglos de Oro", Iberoromania, 62:2, 44-58.

CASTillo LluCH, Mónica (2002) “Distribución de las formas analíticas y sintéticas de futuro y condicional en español medieval", in María Teresa Echenique \& Juan Sánchez Méndez (eds.), Actas del V Congreso Internacional de Historia de la Lengua Española, vol. I. Madrid: Gredos, 541-549.

Castillo lluch, Mónica \& Octavio de Toledo y Huerta, Álvaro (2016) "Habemos muchos que hablamos español: distribución e historia de la concordancia existencial en primera persona 
de plural", in Carlota de Benito Moreno \& Álvaro Octavio de Toledo (eds.), En torno a haber: construcciones, usos y variación desde el latín hasta la actualidad, Frankfurt a.M.: Peter Lang, 111-168.

CATALÁN, Diego (1972) “De Nájera a Salobreña. Notas lingüísticas e históricas sobre un reino en estado latente", in Studia hispanica in honorem Rafael Lapesa, vol. III, Madrid: Gredos, 97-121.

Coello MesA, Antonia María (2004) “Contribución al estudio del sistema preposicional en el castellano de la Edad Media", Revista de Filología de la Universidad de la Laguna, 22, 55-66.

Company Company, Concepción (2006) "Tiempos de formación romance II. Los futuros y condicionales", in Concepción Company Company (ed.), Sintaxis histórica de la lengua española, vol. I.1, México: UNAM / FCE, 349-422.

Company Company, Concepción (2007) El siglo XVIII y la identidad lingüística de México, México: Universidad Nacional Autónoma de México / Academia Mexicana de la Lengua.

CORDE = Real Academia Española (2000-) Corpus Diacrónico del Español [online resource], <http://corpus.rae.es/cordenet.html>.

COROMInAS, Joan \& José Antonio PASCUAL (1980-1991) Diccionario crítico etimológico castellano e hispánico, Madrid: Gredos.

CREA = Real Academia Española (2000-): Corpus de Referencia del Español Actual [online resource], $<$ http://corpus.rae.es/creanet.html>.

DELPORT, Marie-France (2004) Deux verbes espagnols: haber et tener, París: Éditions Hispaniques.

Díaz-Trechuelo, María Lourdes (1991) "La emigración familiar andaluza a América en el siglo XVII", in Antonio Eiras Roel (ed.), La emigración española a Ultramar, 1492-1914, Madrid: Ediciones Tabapress, 189-197.

EBERENZ, Rolf (1991) “Castellano antiguo y español moderno: reflexiones sobre la periodización en la historia de la lengua", Revista de Filología Española, 71, 79-106.

EBERENZ, Rolf (2008) "Sobre relaciones espaciales: los adverbios de localización vertical suso-arriba vs. yusoabajo en el español preclásico y clásico", in Concepción Company Company \& José G. Moreno de Alba (eds.), Actas del VII Congreso Internacional de Historia de la Lengua Española, vol. I. Madrid: Arco Libros, 537-552.

EBERENZ, Rolf (2009) “La periodización de la historia morfosintáctica del español: propuestas y aportaciones recientes", Cahiers d'Études Hispaniques Médievales, 32, 181-201.

EnRIQue-Arias, Andrés (2012) “Dos problemas en el uso de corpus diacrónicos del español: perspectiva y comparabilidad", Scriptum Digital, 1, 85-106. 
ENRIQUe-ArIAS, Andrés (2018) "Factores diatópicos en la variación entre este y aqueste en la historia del español", in María Luisa Arnal et al. (eds.), Actas del X Congreso Internacional de Historia de la Lengua Española, vol. II, Zaragoza: Fundación Fernando el Católico, 1553-1569.

ENRIQUE-ARIAS, Andrés (2019) “Los clíticos de primera y segunda persona del plural en las variedades rurales del español y romances vecinos", Revue de Linguistique Romane, 329-330, 23-75.

Espinosa EloRza, Rosa María (2010) Procesos de formación y cambio en las llamadas "palabras gramaticales", Logroño: Cilengua.

FERNÁNDEZ-ORdóÑEZ, Inés (2001) "Hacia una dialectología histórica. Reflexiones sobre la historia del leísmo, el laísmo y el loísmo", Boletín de la Real Academia Española, 81, 389-464.

FernándeZ-Ordóñez, Inés (2004) "Alfonso X en la historia del español”, in Rafael Cano (ed.), Historia de la lengua española, Barcelona: Ariel, 381.422.

Fernández-OrdóÑEZ, Inés (2006-2007): "Del Cantábrico a Toledo: el neutro de materia hispánico en un contexto románico y tipológico", Revista de Historia de la Lengua Española, 1, 67-118 / 2, 29-81.

FERNÁNDEZ-ORdóÑEZ, Inés (2010) “Menéndez Pidal and the beginnigs of Ibero-Romance dialectology: a critical survey one century later", in Juan Carlos Conde (ed.), Ramón Menéndez Pidal after forty years: a reassessment, London: Queen Mary University, 113-145.

FERnández-ORdóñez, Inés (2011) La lengua de Castilla y la formación del español, Madrid: Real Academia Española.

Fischer, Olga, Ans van Kemenade, Willem Koopman \& Wim van den WURfF (2000) The syntax of Early English, Cambridge: Cambridge University Press.

FLoRES, Marcela \& Chantal Mels (2015) "Periodización del español. Evidencia para una tercera etapa evolutiva", Études Romanes de Brno, 36:2, 11-28.

FLóREZ, Enrique (1767) España sagrada: theatro geographico-historico de la iglesia de España, vol. XXII, Madrid: Antonio Marín.

Frago Gracia, Juan Antonio (1982) "Toponimia navarroaragonesa del Ebro (IV): orónimos", Archivo de Filología Aragonesa, 30-31, 23-62.

Frago Gracia, Juan Antonio (1999) Historia del español de América: textos y contextos, Madrid: Gredos.

Garachana Camarero, Mar (1997) "Acerca de los condicionamientos cognitivos y lingüísticos de la sustitución de aver por tener", Verba, 24, 203-235.

Garachana Camarero, Mar (2014) "Gramática e historia textual en la evolución de los marcadores discursivos: el caso de no obstante", RILCE, 30:3, 959-984.

Garachana Camarero, Mar (2016) “La expresión de la obligación en la Edad Media. Influencias orientales y latinas en el empleo de ser tenudo / tenido $\{\varnothing$ / a / de $\}$ + infinitivo", in Araceli López Serena, Antonio Narbona \& Santiago del Rey (eds.), El español a través del tiempo: estudios ofrecidos a Rafael Cano Aguilar, vol. I, Seville_Universidad de Sevilla, 497-514.

GarateA, Carlos (2005) El problema del cambio lingüístico en Ramón Menéndez Pidal: el individuo, las tradiciones y la historia, Tübingen: Narr. 
GIRÓN ALCONCHEL, José Luis (2007) “De nuevo sobre la gramaticalización del futuro analítico”, in Inmaculada Delgado \& Alicia Puigvert (eds.), Ex admiratione et amicitia: homenaje a Ramón Santiago, vol. I, Madrid: Ediciones del Orto, 563-576.

Gomila AlBAL, Marina (2016) "Sobre el origen y la difusión geográfica de las formas nosotros y vosotros en castellano", Iberoromania, 83, 103-125.

HEAP, David \& Enrique Pato (2012) "Plurales anómalos en los dialectos y en la historia del español”, in Emilio Montero Cartelle (ed.), Actas del VIII Congreso Internacional de Historia de la Lengua Española, Madrid: Arco Libros, vol. II, 1765-1776.

Hernández-Campoy, Juan Manuel \& Juan Camilo Conde Silvestre (eds.) (2012) The handbook of historical sociolinguistics., Malden (Massachussets): Wiley / Blackwell.

HeRnÁNDEZ DíAZ, Axel (2006) “Posesión y existencia. La competencia de haber y tener y haber existencial”, in Concepción Company Company (ed.), Sintaxis histórica de la lengua española, vol. I:2, México: FCE / UNAM, 1053-1160.

KABATEK, Johannes (2013) “¿Es posible una lingüística histórica basada en un corpus representativo?”, Iberoromania, 77, 8-28.

LHP = LAPESA, Rafael, et al. (2003) Léxico hispánico primitivo, Madrid: Real Academia Española / Fundación Ramón Menéndez Pidal / Espasa Calpe.

LIPSKI, John M. (2014): "The many facets of Spanish dialect diversification in Latin America", in Salikoko S. Mufwene, Iberian imperialism and language evolution in Latin America, Chicago: The University of Chicago Press, 38-75.

MALKIEL, Yakov (1945) “Old Spanish nadi(e), otri(e)”, Hispanic Review, 13, 204-230.

MALKIEL, Yakov (1948) Hispanic algu(i)en and related formations: a study of the stratification of the Romance lexicon in the Iberian Peninsula, Berkeley: University of California Press.

Martínez AlCAlde, María José \& Mercedes Quilis Merín (1996) “Nuevas observaciones sobre periodización en la historia de la lengua española", in Alegría Alonso et al. (eds.), Actas del III Congreso Internacional de Historia de la Lengua Española, vol. I, Madrid: Arco Libros / Fundación Duques de Soria, 873-885.

Martínez ShaW, Carlos (2004) La España moderna (1474-1700), in Rafael Cano (ed.), Historia de la lengua española, Barcelona: Ariel, 659-680.

MATUTE, Cristina (2013) "Hacia una caracterización dialectal de la interpolación en el castellano de la Edad Media", in Emili Casanova \& Cesáreo Calvo (eds.), Actas del XXVI Congreso Internacional de Lingüística y de Filología Románicas, Berlin / Boston: De Gruyter, 155-164.

MATUte, Cristina (2016) "Entre pronombres y adverbios: mecanismo de cambio en la historia dialectal peninsular de hi/ý< < IBI", Boletín de la Real Academia Española, 96, 201-237.

MeILlET, Antoine (1929) "Une enquête linguistique universelle", Bulletin de la Société Linguistique de Paris, 29, 77-81. 
Melis, Chantal, Marcela Flores \& Sergio Bogard (2003) "La historia del español. Propuesta de un tercer periodo evolutivo", Nueva Revista de Filología Hispánica, 51:1, 1-56.

MENÉNDEZ PIDAL, Ramón (1916 [21950]) Orígenes del español: estado lingüístico de la Península lbérica hasta el siglo XI, Madrid: Espasa Calpe.

MenÉndez PIDAL, Ramón (1962) "Sevilla frente a Madrid. Algunas precisiones sobre el español de América", in Estructuralismo e historia. Miscelánea Homenaje a André Martinet, vol. III, San Cristóbal de La Laguna: Universidad de La Laguna, 99-165.

MoRAL del HoYo, Carmen (2015) "Hacia una dialectología gramatical del castellano medieval: cuestiones morfológicas del imperfecto y futuro de subjuntivo", Scriptum Digital, 4, 143-164.

Morala, José Ramón (2002) "De la complejidad interna del castellano en Castilla (y León)", in Carmen Saralegui \& Manuel Casado (eds.), Pulchre, bene, recte. Estudios en homenaje al Prof. Fernando González Ollé, Pamplona: Eunsa, 955-969.

OCtAVIO de Toledo y HUERTA, Álvaro S. (2015a) "Futuros que se miran el ombligo: mesoclisis y anteposición de formas no personales en la historia del español", in Mónica Castillo Lluch \& Marta López Izquierdo (eds.), El orden de palabras en la historia del español y otras lenguas iberorromances, Madrid: Visor Libros, 141-233.

Octavio de Toledo y HuerTA, Álvaro S. (2015b) "La oculta vida dialectal de bajo + SN", in José María García Martín (ed.), Actas del IX Congreso Internacional de Historia de la Lengua Española, vol. II, Madrid / Frankfurt a. M.: Iberoamericana / Vervuert, 1841-1858.

Octavio de Toledo y HueRTA, Álvaro S. (2016a) Los relacionantes locativos en la historia del español, Berlin / Boston: De Gruyter Mouton (Beihefte zur Zeitschrift für Romanische Philologie, 403).

Octavio de Toledo y HUeRTA, Álvaro S. (2016b) "Sin CORDE pero con red: algotras fuentes de datos", Revista Internacional de Lingüística Iberoamericana (RILI), 28, 19-47.

Octavio de Toledo y HUeRTA, Álvaro S. (2016c) "De Valencia a Sinaloa: la doble gramaticalización de en igual de", in Araceli López Serena, Antonio Narbona \& Santiago del Rey (eds.), El español a través del tiempo: estudios ofrecidos a Rafael Cano Aguilar, vol. I, Sevilla: Universidad de Sevilla, 653-673.

OctaVIO de Toledo y HUERTA, Álvaro S. (2016d) “El aprovechamiento del CORDE para el estudio sintáctico del primer español moderno (ca. 1675-1825)", in Johannes Kabatek (ed.), Lingüistica de corpus y lingüística histórica iberorrománica, Berlin / Boston: De Gruyter, 57-89.

Octavio de Toledo y HUeRTA, Álvaro S. (2017a) "Juan de Mena como traductor: aspectos lingüísticos del Omero romançado", in Heidi Aschenberg \& Sarah Dessì-Schmidt (eds.), Romanische Sprachgeschichte und Übersetzung, Heidelberg: Winter, 53-114.

Octavio de Toledo y HuerTA, Álvaro S. (2017b): “El pretérito perfecto de subjuntivo en la Edad Media: distribución dialectal y entornos sintácticos", Moenia, 23, 317-366.

Octavio de Toledo y HUerTA, Álvaro S. (2018a) “Orónimos dialectales y morfosintaxis histórica: el método pidalino y las formaciones adverbiales con cima y somo", Boletín de la Real Academia Española 98:317, 267-313. 
Octavio de Toledo y HuertA, Álvaro S. (2018b) "Paradigmaticisation through formal ressemblance: a history of the reinforcer bien in Spanish discourse markers", in Salvador Pons Bordería \& Óscar Loureda Lamas (eds.), Beyond grammaticalization and discourse markers: New issues in the study of language change, Leiden: Brill (Brill's Studies in Pragmatics).

Octavio de Toledo y Huerta, Álvaro S. \& Mónica Castillo Lluch (2016) "Habemos muchos que hablamos español: distribución e historia de la concordancia existencial en primera persona de plural", in Carlota de Benito Moreno \& Álvaro Octavio de Toledo (eds.), En torno a haber: construcciones, usos y variación desde el latín hasta la actualidad, Frankfurt a. M. [etc.]: Peter Lang, 111-168.

Octavio de Toledo y Huerta, Álvaro S. \& Cristina SÁnChez lópez (2007) “Variación sintáctica y espacio dialectal: a propósito de los cuantificadores interrogativos y exclamativos", in César Hernández Alonso and Leticia Castañeda (eds.), El español de América: actas del VI Congreso Internacional, Valladolid: Diputación de Valladolid, 839-855.

Octavio de Toledo y Huerta, Álvaro S. \& Cristina Sánchez lópez (2009) “Cuantificadores II. Cuantificadores interrogativos y exclamativos", in Concepción Company Company (ed.), Sintaxis histórica de la lengua española, vol. II.2, Mexico: UNAM / FCE, 961-1071.

OesterReicher, Wulf (2006) “La historicidad del lenguaje: variación, diversidad y cambio lingüístico", in José Jesús de Bustos \& José Luis Girón (eds.), Actas del VI Congreso Internacional de Historia de la Lengua Española, vol. I, Madrid: Arco Libros, 137-158.

Oesterreicher, Wulf (2007) “Historicismo y teleología: el Manual de gramática histórica española en el marco del comparatismo europeo", Lexis, 31, 277-304.

OJEDA NIETO, José (2004) “La población de España en el siglo XVII: tratamiento demográfico de la bula de la Santa Cruzada", Revista de Història Moderna i Contemporània (HmiC), 2, 77-117.

Paredes García, Florentino (2015) “Factores condicionantes de la variación otro / otri / otre / otrie en español medieval”, in Juan Pedro Sánchez Méndez, Mariela de la Torre \& Viorica Codita (eds.), Temas, problemas y métodos para la edición y el estudio de documentos hispánicos antiguos, Valencia: Tirant lo Blanch, 227-260.

PAто, Enrique (2009) “Notas aclaratorias sobre la historia del indefinido alguien: una aplicación directa del uso de corpus diacrónicos", in Andrés Enrique-Arias (ed.), Diacronía de las lenguas iberorrománicas. Nuevas aportaciones desde la lingüística de corpus, Madrid / Frankfurt: Iberoamericana / Vervuert, 400-416.

PATO, Enrique (2013) "Sobre la forma muncho", Estudios de Lingüística de la Universidad de Alicante (ELUA), $27,329-342$.

PENNY, Ralph (2004) Variation and change in Spanish, Cambridge: Cambridge University Press.

PONs RodrígueZ, Lola (2015) “La lengua del Cuatrocientos más allá de las Trescientas”, en José María García Martín (ed.), Actas del IX Congreso Internacional de Historia de la Lengua Española, vol. I, Madrid / Frankfurt: Iberoamericana / Vervuert, 393-433. 
RIDRUejo, Emilio (1984) "Tres catalanismos (y aragonesismos) sintácticos en Los doze trabajos de Hércules del marqués de Villena", Archivo de Filología Aragonesa 34-35, 273-290.

Rodríguez Molina, Javier (2010) La gramaticalización de los tiempos compuestos en español antiguo: cinco cambios diacrónicos, Unpublished PhD, Madrid, Universidad Autónoma de Madrid.

Rodríguez Molina, Javier (2012) "La reducción fonética avemos cantado > hemos cantado en español antiguo: nuevos datos y nuevas hipótesis", in Enrique Pato \& Javier Rodríguez Molina (eds.), Estudios de filología y lingüística españolas. Nuevas voces en la disciplina, Bern [etc.]: Peter Lang, 134-175

RodríGUez Molina, Javier (2015) "El adverbio así en español medieval: variantes morfofonéticas", in José María García Martín (ed.), Actas del IX Congreso Internacional de Historia de la lengua Española, vol. I, Frankfurt / Madrid: Iberoamericana / Vervuert, 1049-1064.

Rodríguez Molina, Javier \& Álvaro S. Octavio de Toledo y Huerta (2017) “La imprescindible distinción ente texto y testimonio: el CORDE y los criterios de fiabilidad lingüística", Scriptum Digital 6, 5-68.

Sánchez Lancis, Carlos (1990) Estudio de los adverbios de espacio y tiempo en el español medieval, Unpublished PhD, Barcelona: Universitat Autònoma de Barcelona.

SÁNCHEZ MÉNDEZ, Juan (2015) "Consideraciones para una morfosintaxis histórica de las hablas americanas", in José María García Martín (ed.), Actas del IX Congreso Internacional de Historia de la Lengua Española, vol. I, Madrid / Frankfurt: Iberoamericana / Vervuert, 227-260.

Sánchez-Prieto Borja, Pedro \& Delfina Vázquez Balonga (2018) “Toledo frente a Madrid en la conformación del español moderno: el sistema pronominal átono", Revista de Filología Española, 98:1, 185-215.

SÁnChez-Prieto Borja, Pedro (2019) “Madrid en la configuración del español moderno", en Mónica Castillo \& Elena Díez del Corral (eds.), Reescribiendo la historia de la lengua española a partir de la edición de documentos, Bern: Peter Lang, 85-112.

StAAFF, Erik (1907) Étude sur l'ancien dialecte léonais, d'après des chartes du XIIle siècle, Uppsala: Almqvist \& Wiksell

Torres Cacoullos, Rena (2011) "Variation and grammaticalization", in Manuel Díaz Campos (ed.), The handbook of Hispanic sociolinguistics, Chichester, Wiley / Blackwell, 148-167.

TRUDGILL, Peter (2011) Sociolinguistic typology: Social determinants of linguistic complexity, Oxford: Oxford University Press.

Tuten, Donald N. \& Fernando Tejedo HerRero (2011) "The Relationship between Historical Linguistics and Sociolinguistics", in Manuel Díaz Campos (ed.), The handbook of Hispanic sociolinguistics, Chichester: Wiley /Blackwell, 148-167, 283-302. 